An Analysis of Freshwater Mussels (Unionidae) Along Luxapalila Creek, Mississippi, 1999 Studies

Andrew C. Miller
US Army Corps of Engineers ${ }_{\circledast}$

Engineer Research and Development Center

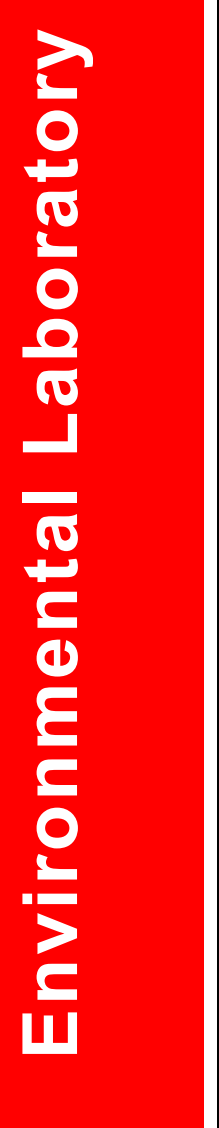

Approved for public release; distribution is unlimited. 
The contents of this report are not to be used for advertising, publication, or promotional purposes. Citation of trade names does not constitute an official endorsement or approval of the use of such commercial products.

The findings of this report are not to be construed as an official Department of the Army position, unless so designated by other authorized documents. 


\title{
An Analysis of Freshwater Mussels (Unionidae) Along Luxapalila Creek, Mississippi, 1999 Studies
}

by Andrew C. Miller

\author{
Environmental Laboratory \\ U.S. Army Engineer Research and Development Center \\ 3909 Halls Ferry Road \\ Vicksburg, MS 39180-6199
}

Final report

Approved for public release; distribution is unlimited 


\section{Contents}

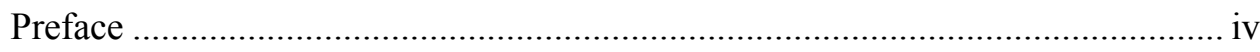

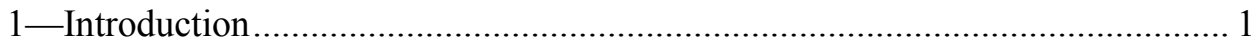

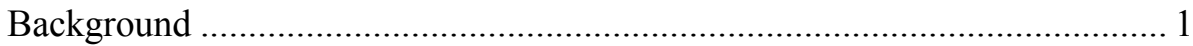

Purpose and Scope

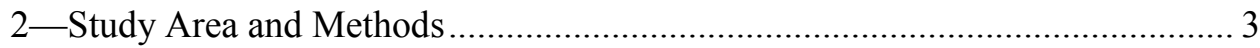

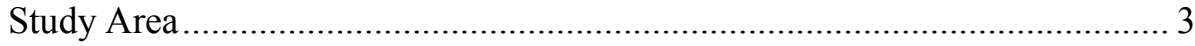

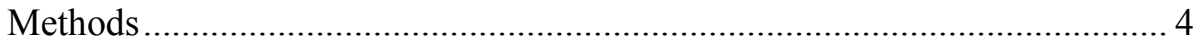

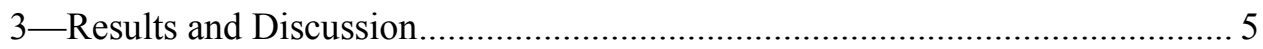

Characterization of the Mussel Resource..................................................... 5

Summary Information on Conditions at Specific Sites Along

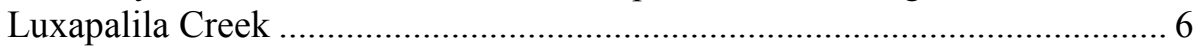

Effects of Channel Modifications on Water Velocity ..................................... 8

Effects of River Stage on Collecting Rate ................................................. 9

Summary and Recommendations ...................................................... 10

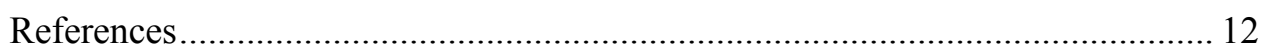

Tables 1-6

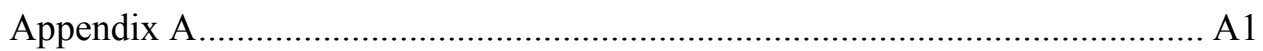

SF 298

\section{List of Figures}

Figure 1. Map of the study area …......................................................... 3

Figure 2. Collection rate (mussels/min) and stage height at Steens, Mississippi when surveys were conducted, Luxapalila Creek, 1997-99

Figure 3. Species richness in Luxapalila Creek based on surveys conducted in 1992 (Hartfield and Bowker 1992) and by personnel of the ERDC in 1997-99 


\section{Preface}

In October 1999, a survey for freshwater mussels was conducted along Luxapalila Creek, Mississippi, between Steens, Mississippi, and Waterworks Road Bridge, River Mile 6.2. The purpose was to obtain information that could be used to assess the effectiveness of reasonable and prudent measures and their terms and conditions to reduce impacts to mussels caused by downstream channelization. In addition, results would be used to determine the likelihood of future losses, or incidental take, of federally listed species in the project area. Studies were conducted by the U.S. Army Engineer Research and Development Center (ERDC), Environmental Laboratory (EL). Staff members from the ERDC conducted similar studies for mussels in 1997 and 1998.

This report was prepared by Dr. Andrew C. Miller, Aquatic Ecology Branch (AEB), Ecological Research Division (ERD), EL, ERDC.

Assistance in the field was provided by: Messrs. Larry Neill, Rob James, Johnny Buchanan, the Tennessee Valley Authority, as well as Mr. Will Green, University of Southern Mississippi. Mr. Brian Peck, U.S. Army Engineer District, Mobile (Planning and Environmental Division), provided maps and other background information.

During the conduct of this study, Dr. Edwin A. Theriot was Acting Director, EL; Dr. Conrad J. Kirby was Chief, ERD, and Dr. Alfred F. Cofrancesco, was Chief, AEB, ERDC.

During the publication of this report, Dr. James R. Houston was Director, ERDC, and COL John W. Morris III, EN, was Commander and Executive Director.

This report should be cited as follows:

Miller, A. C. (2001). "An analysis of freshwater mussels (Unionidae) along Luxapalila Creek, Mississippi, 1999 studies,"

ERDC/EL TR-01-26, U.S. Army Engineer Research and Development Center, Vicksburg, MS.

The contents of this report are not to be used for advertising, publication, or promotional purposes. Citation of trade names does not constitute an official endorsement or approval of the use of such commercial products. 


\section{Introduction}

\section{Background}

Channelization and widening of the Columbus reach of Luxapalila Creek, located in east-central Mississippi, began in September 1994. Work started at River Mile (RM) 2.1, moved upriver until December of that year, and then resumed in June 1995. Work continued through December 1995 when high flow prevented completion of the final $0.37 \mathrm{~km}(0.2$ miles $)$ of the upper Columbus reach. The final $0.37 \mathrm{~km}$ (0.2 miles), up to RM 6.0, was completed in 1996. During this period, the reach immediately upriver of Waterworks Road Bridge (RM 6.2) was unprotected from higher water velocities and decreased water surface elevations that resulted from the increased slope and drainage efficiency of the downstream reach. On 15 March 1996, the U.S. Fish and Wildlife Service (USFWS) contacted the U.S. Army Engineer District, Mobile (CESAM), about Luxapalila Creek. They had received information from the Mississippi Department of Wildlife, Fisheries, and Parks (MDWFP), concerning degradation upriver of Waterworks Road Bridge. A site visit revealed stream bank erosion and undercutting, bank failure with fallen trees, increased water velocities, decreased water surface elevations, recent gravel bar reworking and deposition, scoured water willow beds, and significant shifts in channel thalweg (USFWS 1996). Field investigations by the MDWFP indicated that the effects of channel instability were continuing and were evident at least up to RM 8.2 (per Mr. Charles Watts as cited by USFWS 1996). These observations suggested that significant channel degradation and erosion had recently occurred in response, at least in part, to the downstream channelization between RM 2.1 and 6.0.

The project area is within the range of the following federally listed endemic mussels: Pleurobema perovatum (ovate clubshell mussel) and Pleurobema decisum (southern clubshell mussel), listed as endangered; and Medionidus acutissimus (Alabama moccasinshell mussel) and Lampsilis perovalis (orangenacre mucket mussel) listed as threatened. These species originally occurred widely in the Tombigbee River drainage, including the Tombigbee River and some of its larger tributaries. These riverine species inhabit high quality, stable gravel or gravelly sands with flowing water.

At the request of the CESAM, the USFWS prepared a Biological Opinion which provided Reasonable and Prudent Measures (RPMs) and their terms and conditions (T\&C) to avoid or minimize incidental 'take' of federally listed mussel species. Among the RPMs and their T\&C to be implemented by the CESAM was 
the monitoring of mussel populations upstream from Waterworks Road Bridge. Results of this monitoring, in conjunction with hydrologic monitoring at selected cross section stations to be conducted by CESAM, would be used to assess the effectiveness of RPMs and their T\&C to reduce impacts to mussels. Results will also be used to determine the likelihood of future losses or incidental take of federally listed species.

The first published list of mussels in Luxapalila Creek was by C.A. Schultz (1981). In addition to reporting on fishes in the Tombigbee River before construction of the Tennessee-Tombigbee Waterway, Mr. Shultz listed freshwater mussels from the entire basin including 13 species from Luxapalila Creek. Personnel from the Mississippi Museum of Natural Science collected mussels in Luxapalila Creek in the 1980s and early 1990s (Hartfield and Bowker 1992).

On 19 August 1997, ten sites between RM 14.6 and 10.1 were searched for mussels by waders and divers using mainly qualitative methods. Specific searches for juvenile mussels were also made by collecting total substratum samples and sieving sediments. On 1 September 1998 the survey was repeated, using nearly the same methods. During 1998, however, divers were not used, since the majority of the mussels were collected by waders in shallow water. In addition, an 11th sample site was added in the 1998 survey. The 1997 and 1998 surveys are reported by Miller (1998) and herein.

On 20 and 21 October 1999, the survey was repeated using only waders and no divers. A total of 14 sites were searched. Previously samples sites were surveyed again, plus three new sites.

\section{Purpose and Scope}

The purpose was to collect information on mussels in Luxapalila Creek upstream of Waterworks Road Bridge to evaluate effects of recent channel modifications and project-induced water velocity changes. 


\section{Study Area and Methods}

\section{Study Area}

Luxapalila Creek begins as three small creeks in western Alabama near the border of Lamar and Pickens counties (Figure 1). The creeks flow west into Mississippi to form Luxapalila Creek in eastern Lowndes county which then joins Yellow Creek, west of Steens, Mississippi. Luxapalila Creek then flows southwest through Columbus where it enters the Tombigbee River. The project area begins near Steens and continues to Waterworks Road Bridge, a distance of approximately $13 \mathrm{~km}$ (7 miles) (Figure 1).

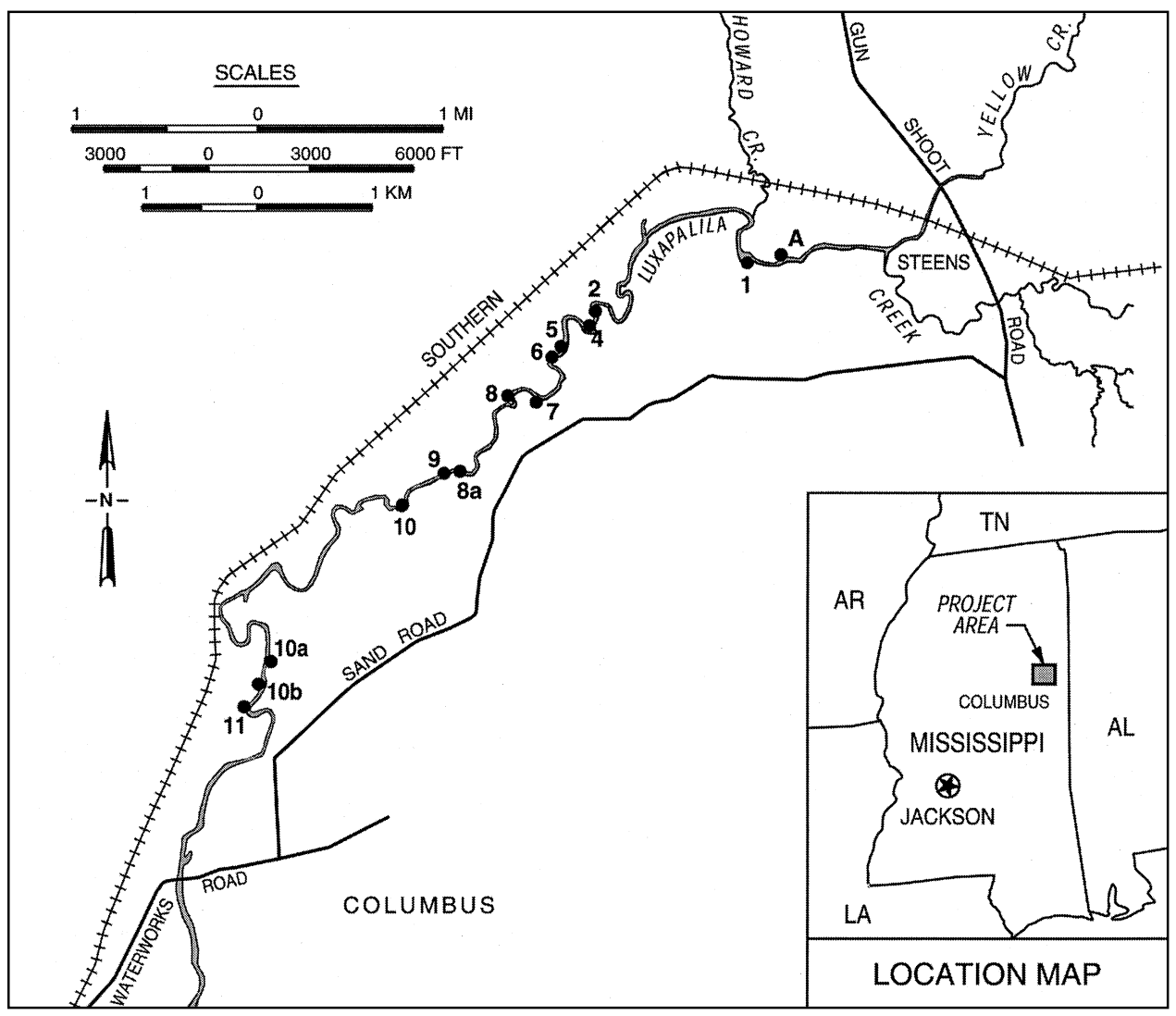

Figure 1. Map of the study area 
Between Steens and the confluence of Yellow Creek, Luxapalila Creek was narrow with steep banks ( 1 to $2 \mathrm{~m}$ ) and sharp bends. There were no exposed shoals and current velocity ranged between 25 and $50 \mathrm{~cm} / \mathrm{sec}(10$ and $20 \mathrm{in} . / \mathrm{sec}$ ). Between the confluence of Yellow Creek and just downriver of the last site sampled, the creek consisted of a sequence of long, narrow pools, runs, and riffles. During the time of the survey, water velocity ranged between 25 and $50 \mathrm{~cm} / \mathrm{sec}$ (10 and $20 \mathrm{in.} / \mathrm{sec}$ ), and the habitat consisted of shallow runs, riffles, and exposed bars. Between the last site sampled and Waterworks Road Bridge, there were fewer exposed gravel shoals, the water was deeper, and velocity was approximately $75 \mathrm{~cm} / \mathrm{sec}(30 \mathrm{in} . / \mathrm{sec})$.

\section{Methods}

Mussels were collected at 14 sites between RM 14.6 and 8.0 (Tables 1 and 2, Figure 1). Sites were identified based upon a reconnaissance of the study area conducted with personnel from the CESAM and USFWS on 14 November 1996 (Miller 1998). Stage height during the first survey, 19 August 1997, was $1.98 \mathrm{~m}$ $(6.5 \mathrm{ft})$, and on 1 September 1998 it was $1.77 \mathrm{~m}(5.80 \mathrm{ft})$. On 20 October 1999 stage height was $1.58 \mathrm{~m}(5.17 \mathrm{ft})$.

All collectors worked and searched for mussels for specific time periods, usually $30 \mathrm{~min}$. They moved on their hands and knees, and collected all live bivalves encountered by touch. Depending on conditions and personal preferences, some collectors used rakes to help search the substratum. In addition and at each site, two to three quantitative, total substratum samples were obtained, and sediments were wet-sieved through a screen series and carefully examined for live juveniles. However, more tedious, total substratum sampling is more likely to obtain live juveniles than qualitative collecting by hand. Total area of bottom sampled quantitatively is listed in Table 2. Virtually the same methods employed in 1997 and 1998 were used in 1999.

At the end of the collecting period, mussels and shells from each site were counted and identified. Representative shells of each species were retained for voucher; most live organisms were returned to the river unharmed. Specimens were compared with shells in the reference collection at the Mississippi Museum of Natural Science. More information on methods for sampling can be found in Isom and Gooch (1986); Kovalak, Dennis, and Bates (1986); Miller and Payne (1988); and, Miller et al. (1993). Mussel taxonomy is consistent with Williams et al. (1993). 


\section{Results and Discussion}

\section{Characterization of the Mussel Resource}

A total of 128 freshwater mussels, representing 15 species including Corbicula fluminea (Asian clam), was collected during the survey in 1999 (Tables 3 through 6). Total search time expended was $930 \mathrm{~min}(15.5 \mathrm{hr}$ ) and ranged from $30 \mathrm{~min}$ at Site 11 to $90 \mathrm{~min}$ at most other sites (Table 3). The greatest number of mussels collected per minute was at Site $6(0.61 / \mathrm{min})$ where eight species were collected. The site with the next most abundant fauna was number 10A, where seven species were collected and 0.36 individuals were collected per minute. At six sites, 15 or less live mussels were collected, and at three sites no live mussels were collected (Table 3). A total of 128 live mussels were collected in 1999. Mussel collecting rates ranged from 0.02 to

0.61 individuals $/ \mathrm{min}$; with a mean rate 0.14 individuals $/ \mathrm{min}$ (Table 3 ). This value for 1999 was virtually the same rate that mussels were collected in 1998.

However, both values were approximately 50 percent greater than the overall collecting rate for 1997.

Using similar techniques, divers have collected up to eight mussels/min in moderate- to high-density beds in the upper Mississippi River, Wisconsin (Miller and Payne 1996), and in the Sunflower River, central Mississippi (Miller and Payne 1995). Density in the majority of these sites along Luxapalila Creek, when compared with medium-sized to large rivers in the central and southeastern United States, is moderate to low. Based upon the results of quantitative sampling, no juvenile mussels were found at most sites. However, very small Quadrula asperata (Alabama orb) were found at Site 6. These specimens were less than $15 \mathrm{~mm}$ and evidence of recruitment probably in early 1999, although possibly in 1998. It is very likely that recruitment is occurring for most species in the Luxapalila Creek; however, the number of juveniles is so low that it is difficult to find them.

Based upon living specimens, the most abundant species were: Quadrula asperata and Lampsilis straminea claibornensis (southern fatmucket) which comprised 31.2 and 19.5 percent of the fauna (Table 3). Both species are relatively common in sand gravel substratum in southern streams. The third and fourth most abundant species, Tritogonia verrucosa (pistolgrip) and Lampsilis ornata (southern pocketbook), each comprised 18.7 and 10.9 percent of the collection. Both species are common in fine-grained sands and silt in lentic or 
lotic habitats in Mississippi. The remaining 11 species each comprised less than 4 percent of the bivalve fauna.

Hartfield and Bowker (1992) searched for bivalves along Luxapalila Creek on 11 and 12 May 1992. Stage height was at $2.29 \mathrm{~m}(7.5 \mathrm{ft})$ during both days. Collections were made by hand; no diving was done. Sampling methods used during both surveys are approximately similar; no divers were used. Hartfield and Bowker (1992) reported on live mussels from the following reaches (moving downriver):

a. Reach 1 - Distance from Steens to the entrance of Yellow Creek

$b$. Reach 2 - Distance from the entrance of Yellow Creek to the mouth of Howard Creek

c. Reach 3 - Distance from the mouth of Howard Creek to the center of section 30 (near our Site 1, Figure 1)

d. Reach 4 - Distance from section 30 through section 36 (downriver of Site 11, Figure 1).

In addition to $C$. fluminea, they collected 11 species of freshwater mussels and 72 individuals (Table 5). Based upon results of their studies and historical information, Hartfield and Bowker (1992) listed 21 species of mussels from Luxapalila Creek. Their list included four previously unreported species: Elliptio arca (Alabama spike), Fusconaia cerina (Gulf pigtoe), Potamilus purpuratus (bleufer), and Megalonaias nervosa (washboard). Of these four previously unreported species, only $F$. cerina was taken alive; the remainder were collected as shells.

When results of 1997, 1998, and 1999 surveys are combined, 22 species of mussels have been collected alive in Luxapalila Creek. Seven species, Anodonta suborbiculata (flat floater), Lasmigonia complanata (white heelsplitter), Obovaria unicolor (Alabama hickorynut), Pyganodon grandis, (giant floater), Leptodea fragilis (papershell), and Quadrula rumphiana (ridged mapleleaf), have not been reported previously from the project area. These species were missed during previous surveys, or they may have been recently introduced. When information from our surveys are combined with information reported by Hartfield and Bowker (1992), the total number of freshwater mussels from Luxapalila Creek is now 27, not counting C. fluminea (Table 6).

\section{Summary Information on Conditions at Specific Sites Along Luxapalila Creek}

Site A. We searched for mussels a total of approximately $90 \mathrm{~min}$ at an exposed gravel bar $500 \mathrm{~m}(1,640 \mathrm{ft})$ upriver of Site 1 (Figure 1). This site was not searched in previous years. No live mussels were collected.

Site 1. In the last 3 years, no more than two species or more than five live mussels have been found at any one time of collecting in a year (Appendix A, 
Table A1). This is a low-density site, and physical conditions have remained the same each year.

Site 2. We found fewer mussels at Site 2 in 1999 than we did during the previous 2 years (Table A1). A total of 17 species have been found at this site, and in the first two survey years more than 50 mussels were collected. It is possible that extreme low water in 1999 exposed live mussels to predation. Physical conditions at this location have not changed since 1997, with the exception of the extreme low water during 1999.

Site 3. As noted in Tables 1, 2, and A2, this site was not worked in 1999 because of extreme low water. Only C. fluminea was found here in the past (Table A2).

Site 4. Eight species were collected at this location in 1998; six were taken in 1999. Conditions at this site have remained similar each year. A total of 10 species have been collected at this site since we began work on this creek (Table A2).

Site 5. Progressively more species and individuals have been collected at this site each year since this work was begun. In 1997, one species was found, and in 1999, five species and 10 live mussels were collected. A total of seven species have been collected at this site during the three survey years (Table A3).

Site 6. More live mussels were taken in 1999 (55 live and 8 different species) than in the two previous years combined. In addition, evidence of recent recruitment (individuals less than the 15-mm total shell length) was found for Q. asperata. Nine species have been taken here in the last 3 years of sampling (Table A3).

Site 7. This has never been a productive site for mussels. Two individuals and species were collected in 1998; none were taken in 1997 and 1999 (Table A4).

Site 8. Five live mussels and two species were taken in 1999 and 1997, although no live mussels were found at this location in 1998. This site, like Site 7, has never had many mussels present (Table A4).

Site 8a. 45-min period was spent searching at an exposed gravel bar upriver of Site 9 (Figure 1). No live mussels or shells were found at this location. This site had not been surveyed in previous years.

Site 9. This has never been a productive location for mussels. Three species were found in 1999 and 1997; a single live species was collected in 1998. A total of four species have been taken at this location (Table A5).

Site 10. Progressively fewer species and live mussels have been collected each year at this location since 1997 (Table A5). Part of the reason for this may be reduced water levels at a slough where the majority of the mussels were taken in 1997. Low water in the slough appeared to be mainly the result of reduced 
water levels in Luxapalila Creek and a tributary stream that feeds the slough. Thirteen species have been taken at this location since 1997.

Site 10a. This site was first surveyed in 1999. A total of 7 species and 16 live mussels were collected in 1999 (Table A6). This is a stable shoal with many depositional areas along the left descending bank where mussels can be found.

Site 10b. This site was first surveyed in 1999. No living mussels were collected at this location (Table A6).

Site 11. This site was first surveyed in 1998. No live mussels were collected in 1998 or 1999 at this location (Table A7).

\section{Effects of Channel Modifications on Water Velocity}

The HEC-2 Model was used to evaluate the effects of completed channel modifications downstream of Waterworks Road Bridge on water velocity (see following text). Differences between pre- and postproject water velocities were least $(3 \mathrm{~cm} / \mathrm{sec}(<0.1 \mathrm{ft} / \mathrm{s}))$ at low discharge and greatest $(10.7 \mathrm{~cm} / \mathrm{s}(>0.35 \mathrm{ft} / \mathrm{s}))$ at high discharge. Mean water velocity values were highest at the downstream portion of the study area. At RM 6.11 and 7.18, mean velocity differences between pre- and postproject conditions were greater than $15.2 \mathrm{~cm} / \mathrm{sec}(0.5 \mathrm{ft} / \mathrm{sec})$. At the most upstream river reaches, differences between pre- and postproject water velocity approached 0 .

The majority of mussel species collected in the 1992 survey by Hartfield and Bowker (1992), and the three surveys conducted by the U.S. Army Engineer Research and Development Center (ERDC), Vicksburg site, were taken between RM 10.1 and 14.3. This reach is approximately $6.45 \mathrm{~km}$ (4 miles) upriver from the reach near Waterworks Road Bridge, where bank failure and erosion took place. When results of the 1992 survey are compared with data from 1997 through 1999, it appears that so far at least, project-induced velocity changes have had virtually no effect on total numbers of species present (Figure 2).

However, it is always possible that impacts of slightly increased velocity, the result of downstream channel modifications, will not be measurable in this river reach for years. For example, water release schedules from Wolf Creek Dam, Tennessee, completed in 1952, eliminated mussel recruitment in the lower Cumberland River. Although unionid recruitment ceased, living adult mussels were collected in the affected reach as late as 1982 (Miller, Rhodes, and Tippit 1984). 


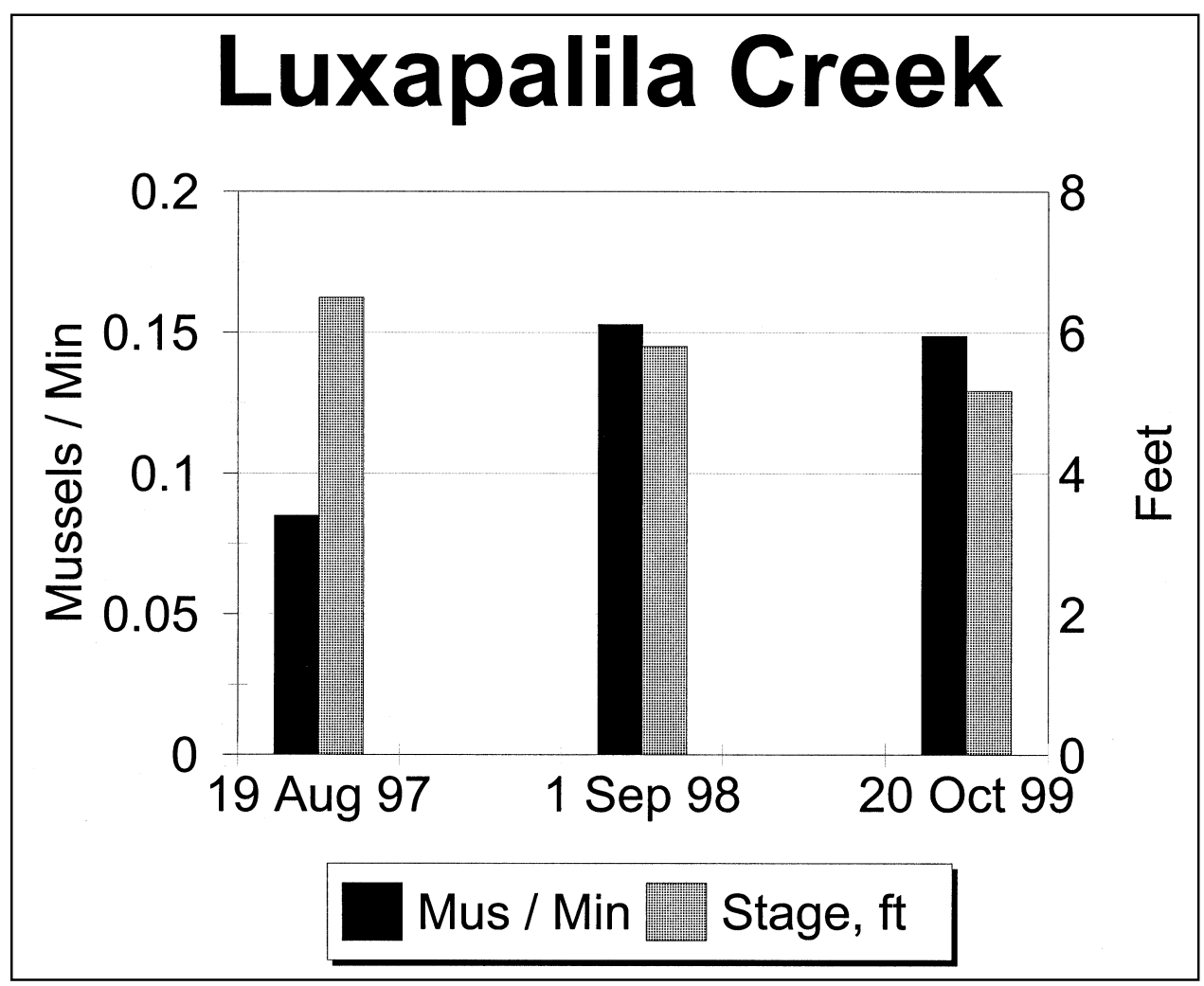

Figure 2. Collection rate (mussels/min) and stage height at Steens, Mississippi, when surveys were conducted, Luxapalila Creek, 1997-1999

\section{Effects of River Stage on Collecting Rate}

Mussel collecting rate in the Luxapalila Creek is influenced by river stage. In 1997, stage height was $2 \mathrm{~m}(6.55 \mathrm{ft})$ and the collecting rate was 0.101 individuals/

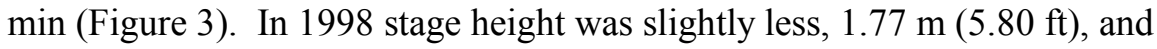
collecting rate was nearly 50 percent greater, with 0.150 individuals collected/ minute. Collecting rates were relatively similar in 1998 and 1999 (0.15 and 0.149 mussels collected per min, respectively), although stage height in 1999 was less than previous years, $1.58 \mathrm{~m}$ (5.17 ft). When Hartfield and Bowker (1992) conducted their survey the stage height was $2.29 \mathrm{~m}(7.5 \mathrm{ft})$, somewhat higher than during previous surveys. Although they did not record the collecting rate, it is very likely that it was negatively affected by water level. Collectors become less efficient as the water becomes deeper, the velocity higher, and it is more difficult to obtain live mussels. 


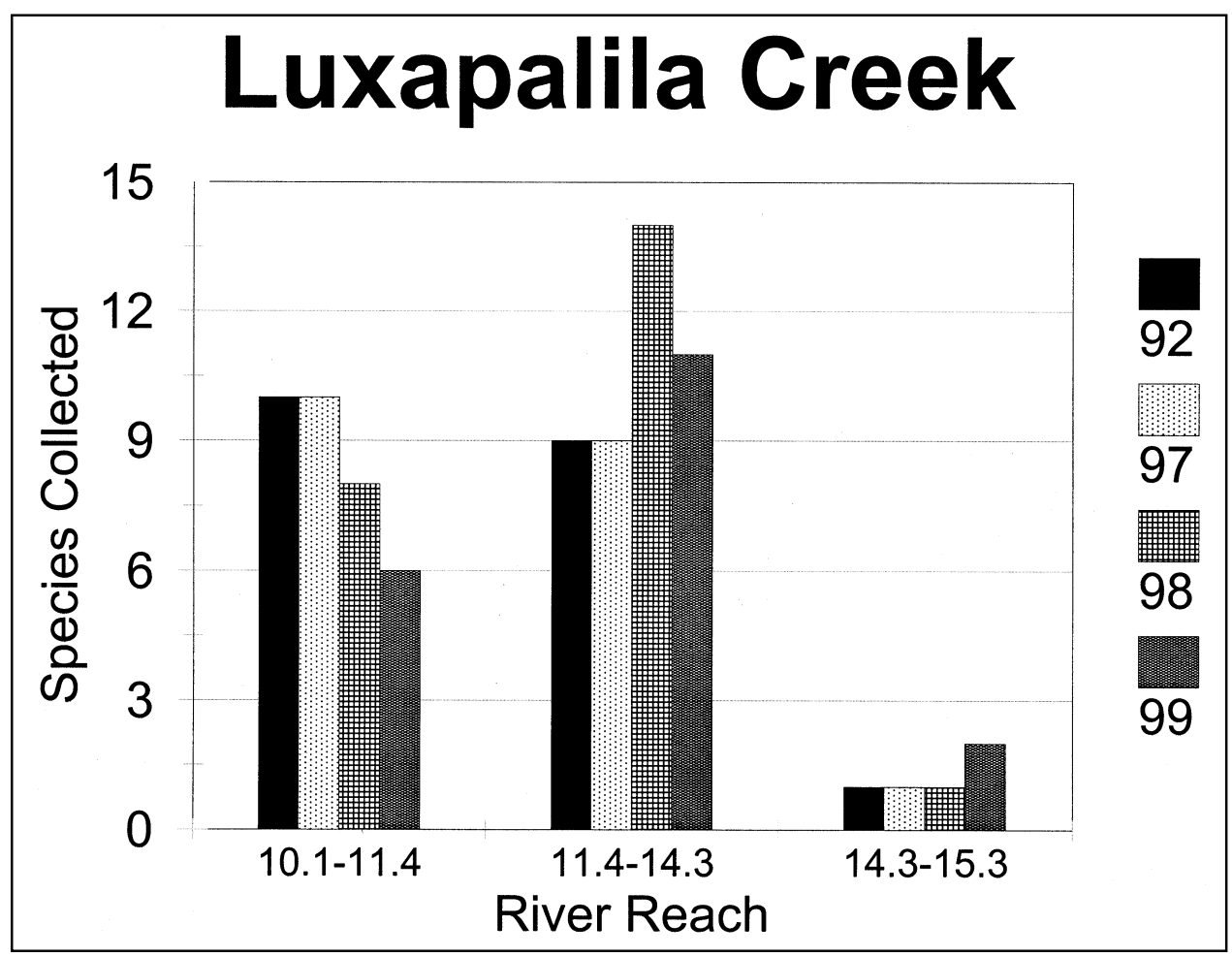

Figure 3. Species richness in Luxapalila Creek based on surveys conducted in 1992 (Hartfield and Bowker 1992) and by personnel of the ERDC in 1997-1999

\section{Summary and Recommendations}

\section{Characterization of the Mussel Resource}

In comparison with other habitats in southern rivers, the mussel fauna of Luxapalila Creek can be described as having moderate to low density. Although shells were commonly found on exposed bars, the number of live mussels found in riffles, runs, or pools was low. Regardless, the total number of mussel species present (27), based upon surveys in 1997 through 1999 as well as that by Hartfield and Bowker (1992), should be considered high for this stream and reflects good water quality and habitat diversity. Typically, larger rivers support greater numbers of mussel species than smaller rivers. The molluscan resource in Luxapalila Creek should be considered valuable because of its high species richness and presence of many uncommon species such as $P$. perovatum, $P$. decisum, and L. perovalis. In 1999 recent recruitment for $Q$. asperata was noted. Although juvenile mussels have always been uncommon in this river, successful recruitment each year is not required to sustain a dense and diverse community. 


\section{Future Studies}

Results of future studies will be important to determine if the altered water velocity is having long-term effects on the mussel fauna. Based on data collected in 1992, 1997, 1998, and 1999, the number of species present has remained essentially unchanged (Figure 2).

Most species collected during these surveys can live to be 20 or more years old. Therefore, results of future studies can be used to determine if present stocks are successfully recruiting. If the same sampling protocol is used (i.e., timed searches), then results can be compared with data collected during the 1997 through 1999 surveys. 


\section{References}

Hartfield, P., and Bowker, R. (1992). "A Mussel survey of Luxapalila Creek, Steens, Mississippi, to the Tombigbee River, May 11-12, 1992." Unpublished Report submitted to the U.S. Army Engineer District, Mobile, from the U.S. Fish and Wildlife Service, Jackson, MS.

Isom, B. G., and Gooch, C. (1986). "Rationale and sampling design for fresh-water mussels, unionidae, in streams, large rivers, impoundments, and lakes,” ASTM STP 894, B. G. Isom (ed.), American Society for Testing and Materials, Philadelphia, PA, 46-59.

Kovalak, W. P., Dennis, S. D., and Bates, J. M. (1986). "Sampling effort required to find rare species of freshwater mussels," ASTM STP 894, B. G. Isom ed., American Society for Testing and Materials, Philadelphia, PA, 34-45.

Miller, A. C. (1998). "An analysis of freshwater mussels (Unionidae) along Luxapalila Creek, Mississippi," Technical Report EL-88-14, U.S. Army Engineer Waterways Experiment Station, Vicksburg, MS.

Miller, A. C., and Payne, B. S. (1988). "The need for quantitative sampling to characterize size demography and density of freshwater mussel communities," American Malacological Bulletin 6, 49-54.

. (1995). "An analysis of freshwater mussels (Unionidae) in the Big Sunflower River, Mississippi, for the Big Sunflower River Maintenance Project: 1993 Studies,” Technical Report EL-95-26, U.S. Army Engineer Waterways Experiment Station, Vicksburg, MS.

. (1996). "Importance of a mussel bed near McMillan Island, Pool 10 of the Upper Mississippi River, for Lampsilis higginsi," Technical Report EL96-9, U.S. Army Engineer Waterways Experiment Station, Vicksburg, MS.

Miller, A. C., Payne, B. S., Shafer, D. J., and Neill, L. T. (1993). "Techniques for monitoring freshwater bivalve communities and populations in large rivers." Proceedings of the Conservation and Management of Freshwater Mussels, October 12-14, 1992. St. Louis, MO.

Miller, A. C., Rhodes, L., and Tippit, R. (1984). "Changes in the naiad fauna of the Cumberland River below Lake Cumberland in Central Kentucky," The Nautilus 98(2), 107-110. 
Schultz, C. A. (1981). "North Mississippi Fisheries Investigations, Mississippi Project F-47," Completion Report Tombigbee River Basin Preimpoundment Studies, Mississippi Department of Wildlife Conservation, Daphne, AL.

U.S. Fish and Wildlife Service. (1996). "Biological opinion on the Corps of Engineers' Luxapalila Creek Flood Control Project, Lowndes County, MS," Unpublished Report submitted to the U.S. Army Engineer District, Mobile, by U.S. Fish and Wildlife Service, Jackson, MS.

Williams, J. D., Warren, M. L., Jr., Cummins, K. S., Harris, J. L., and Neves, R. J. (1993). "Conservation status of freshwater mussels of the United States and Canada," Fisheries 18(9), 6-22. 


\begin{tabular}{|c|c|c|c|c|}
\hline \multicolumn{5}{|c|}{$\begin{array}{l}\text { Table } 1 \\
\text { Global Positioning System Coordinates, Luxapalila Creek, } \\
\text { Mississippi, } 1999\end{array}$} \\
\hline WayPoint & Site & Notes & Latitude (N) & Longitude (W) \\
\hline 1 & A & New in 1999 & 33.56445 & 88.33603 \\
\hline 2 & 1 & & 33.564413 & 88.33948 \\
\hline 3 & 2 & & 33.560421 & 88.35434 \\
\hline ND & 3 & Dry in 1999 & & \\
\hline 4 & 4 & & 33.558925 & 88.35477 \\
\hline 5 & 5 & & 33.556978 & 88.35761 \\
\hline 6 & 6 & & 33.556519 & 88.35841 \\
\hline 7 & 7 & & 33.552997 & 88.36036 \\
\hline 8 & 8 & & 33.553308 & 88.36271 \\
\hline 9 & 9 & & 33.546925 & 88.36958 \\
\hline 10 & 10 & & 33.544543 & 88.37296 \\
\hline 11 & $8 \mathrm{~A}$ & New in 1999 & 33.547201 & 88.36769 \\
\hline 12 & $10 \mathrm{~B}$ & New in 1999 & 33.529887 & 88.38696 \\
\hline 13 & $10 \mathrm{~A}$ & New in 1999 & 33.531808 & 88.38625 \\
\hline 14 & 11 & New in 1998 & 33.528332 & 88.38846 \\
\hline
\end{tabular}




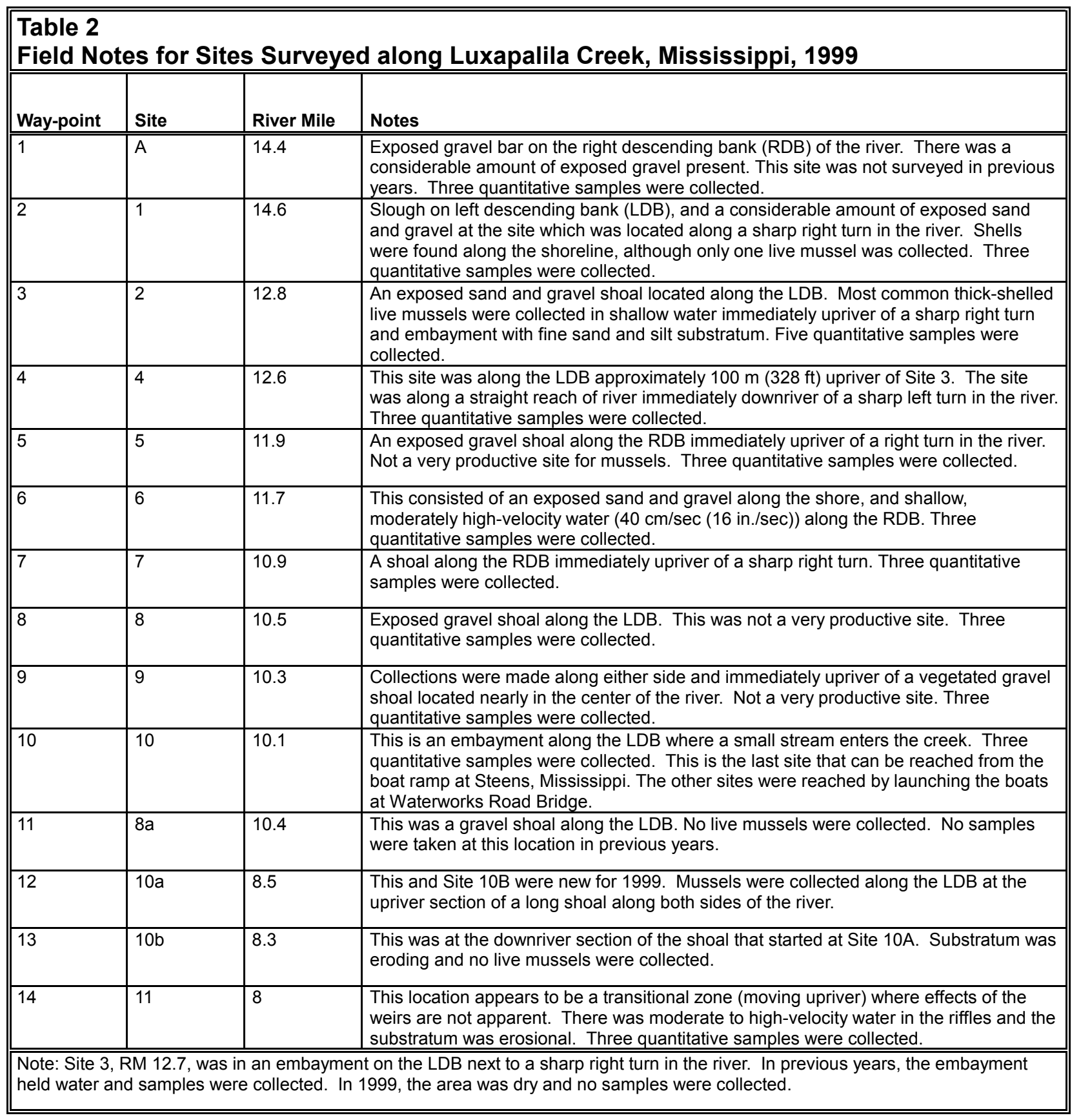




\begin{tabular}{|c|c|c|c|c|c|c|c|c|c|c|c|c|c|}
\hline \multirow[b]{2}{*}{ Scientific Name } & \multicolumn{13}{|c|}{ Site Number } \\
\hline & 1 & 2 & 3 & 4 & 5 & 6 & 7 & 8 & 9 & 10 & $10 a$ & $10 \mathrm{~b}$ & 11 \\
\hline Quadrula asperata & 0.00 & 46.67 & 0.00 & 33.33 & 0.00 & 40.00 & 0.00 & 0.00 & 0.00 & 37.50 & 31.25 & 0.00 & 0.00 \\
\hline Lampsilis s. claibornensis & 0.00 & 20.00 & 0.00 & 11.11 & 0.00 & 21.82 & 0.00 & 80.00 & 33.33 & 0.00 & 18.75 & 0.00 & 0.00 \\
\hline Tritogonia verrucosa & 75.00 & 0.00 & 0.00 & 22.22 & 50.00 & 10.91 & 0.00 & 0.00 & 50.00 & 25.00 & 18.75 & 0.00 & 0.00 \\
\hline Lampsilis ornata & 25.00 & 6.67 & 0.00 & 11.11 & 20.00 & 10.91 & 0.00 & 20.00 & 0.00 & 25.00 & 0.00 & 0.00 & 0.00 \\
\hline Fusconaia cerina & 0.00 & 6.67 & 0.00 & 11.11 & 10.00 & 0.00 & 0.00 & 0.00 & 16.67 & 0.00 & 6.25 & 0.00 & 0.00 \\
\hline Villosa lienosa & 0.00 & 0.00 & 0.00 & 0.00 & 0.00 & 7.27 & 0.00 & 0.00 & 0.00 & 12.50 & 0.00 & 0.00 & 0.00 \\
\hline Toxolasma parva & 0.00 & 6.67 & 0.00 & 0.00 & 0.00 & 3.64 & 0.00 & 0.00 & 0.00 & 0.00 & 0.00 & 0.00 & 0.00 \\
\hline Lampsilis perovalis & 0.00 & 0.00 & 0.00 & 11.11 & 0.00 & 3.64 & 0.00 & 0.00 & 0.00 & 0.00 & 0.00 & 0.00 & 0.00 \\
\hline Pleurobema decisum & 0.00 & 0.00 & 0.00 & 0.00 & 0.00 & 0.00 & 0.00 & 0.00 & 0.00 & 0.00 & 12.50 & 0.00 & 0.00 \\
\hline Elliptio crassidens & 0.00 & 0.00 & 0.00 & 0.00 & 10.00 & 0.00 & 0.00 & 0.00 & 0.00 & 0.00 & 6.25 & 0.00 & 0.00 \\
\hline Obovaria jacksoniana & 0.00 & 6.67 & 0.00 & 0.00 & 0.00 & 0.00 & 0.00 & 0.00 & 0.00 & 0.00 & 0.00 & 0.00 & 0.00 \\
\hline Quadrula rumphiana & 0.00 & 0.00 & 0.00 & 0.00 & 10.00 & 0.00 & 0.00 & 0.00 & 0.00 & 0.00 & 0.00 & 0.00 & 0.00 \\
\hline Potamilus purpuratus & 0.00 & 6.67 & 0.00 & 0.00 & 0.00 & 0.00 & 0.00 & 0.00 & 0.00 & 0.00 & 0.00 & 0.00 & 0.00 \\
\hline Lampsilis teres & 0.00 & 0.00 & 0.00 & 0.00 & 0.00 & 1.82 & 0.00 & 0.00 & 0.00 & 0.00 & 0.00 & 0.00 & 0.00 \\
\hline Elliptio arctata & 0.00 & 0.00 & 0.00 & 0.00 & 0.00 & 0.00 & 0.00 & 0.00 & 0.00 & 0.00 & 6.25 & 0.00 & 0.00 \\
\hline Total individuals & 4 & 15 & 0 & 9 & 10 & 55 & 0 & 5 & 6 & 8 & 16 & 0 & 0 \\
\hline Total species & 2 & 7 & 0 & 6 & 5 & 8 & 0 & 2 & 3 & 4 & 7 & 0 & 0 \\
\hline Total time $(\mathrm{min})$ & 90 & 90 & 0 & 90 & 90 & 90 & 90 & 90 & 90 & 90 & 45 & 45 & 30 \\
\hline Total time (hr) & 1.5 & 1.5 & 0 & 1.5 & 1.5 & 1.5 & 1.5 & 1.5 & 1.5 & 1.5 & 0.75 & 0.75 & 0.5 \\
\hline Individuals/min & 0.04 & 0.17 & 0.00 & 0.02 & 0.11 & 0.61 & 0.00 & 0.06 & 0.07 & 0.09 & 0.36 & 0.00 & 0.00 \\
\hline
\end{tabular}




\begin{tabular}{|c|c|c|c|c|c|}
\hline \multicolumn{6}{|c|}{$\begin{array}{l}\text { Table } 4 \\
\text { Summary Information on Freshwater Mussels Collected Along Luxapalila Creek, } \\
\text { Mississippi, } 1999\end{array}$} \\
\hline Scientific Name & Common Name & Total & $\%$ & Freq & $\%$ \\
\hline Quadrula asperata & Alabama orb & 40 & 31.25 & 5 & 38.46 \\
\hline Lampsilis s. claibornensis & Southern fatmucket & 25 & 19.53 & 6 & 46.15 \\
\hline Tritogonia verrucosa & Pistolgrip & 24 & 18.75 & 7 & 53.85 \\
\hline Lampsilis ornata & Southern pocketbook & 14 & 10.94 & 7 & 53.85 \\
\hline Fusconaia cerina & Gulf pigtoe & 5 & 3.91 & 5 & 38.46 \\
\hline Villosa lienosa & Little spectaclecase & 5 & 3.91 & 2 & 15.38 \\
\hline Toxolasma parva & Lilliput & 3 & 2.34 & 2 & 15.38 \\
\hline Lampsilis perovalis & Orange-nacre mucket & 3 & 2.34 & 2 & 15.38 \\
\hline Pleurobema decisum & Southern clubshell & 2 & 1.56 & 1 & 7.69 \\
\hline Elliptio crassidens & Elephant-ear & 2 & 1.56 & 2 & 15.38 \\
\hline Obovaria jacksoniana & Southern hickorynut & 1 & 0.78 & 1 & 7.69 \\
\hline Quadrula rumphiana & Ridged mapleleaf & 1 & 0.78 & 1 & 7.69 \\
\hline Potamilus purpuratus & Bleufer & 1 & 0.78 & 1 & 7.69 \\
\hline Lampsilis teres & Yellow sandshell & 1 & 0.78 & 1 & 7.69 \\
\hline Elliptio arctata & Delicate spike & 1 & 0.78 & 1 & 7.69 \\
\hline Total individuals & & 128 & & & \\
\hline Total species & & 15 & & & \\
\hline Total sites & & 15 & & & \\
\hline Total time (min) & & 930 & & & \\
\hline Individuals/min & & 0.149 & & & \\
\hline
\end{tabular}




\begin{tabular}{|c|c|c|c|c|c|}
\hline \multicolumn{6}{|c|}{\begin{tabular}{|l} 
Table 5 \\
Percentage Abundance of Freshwater Mussels in Luxapalila Creek, Mississippi, Based \\
Upon a Survey by Hartfield and Bowker (1992) and Surveys Conducted in 1997-99 by \\
ERDC. (ND = No data)
\end{tabular}} \\
\hline \multirow[b]{2}{*}{ Species } & \multirow[b]{2}{*}{ Common Name } & \multirow{2}{*}{$\begin{array}{l}\text { Hartfield \& Bowker } \\
1992\end{array}$} & \multicolumn{3}{|c|}{ ERDC Surveys } \\
\hline & & & 1997 & 1998 & 1999 \\
\hline Anodonta suborbiculata & Flat floater & & 0.86 & & \\
\hline Elliptio arctata & Delicate spike & & & 2.11 & .78 \\
\hline Elliptio arca & Alabama spike & & & & \\
\hline Elliptio crassidens & Elephant-ear & & & 0.70 & 1.56 \\
\hline Fusconaia cerina & Gulf pigtoe & 6.94 & 4.31 & 2.11 & 3.91 \\
\hline Lampsilis s. claibornensis & Southern fatmucket & 12.5 & 0.69 & 11.27 & 19.53 \\
\hline Lampsilis ornata & Southern pocketbook & 16.67 & 11.21 & 12.68 & 10.94 \\
\hline Lampsilis perovalis & Orange-nacre mucket & & 0.86 & & 2.34 \\
\hline Lampsilis teres & Yellow sandshell & & 0.86 & 0.70 & 0.78 \\
\hline Lasmigonia c. complanata & White heelsplitter & & 0.86 & & \\
\hline Leptodea fragilis & Papershell & & & 0.70 & \\
\hline Medionidus acutissimus & Alabama moccasinshell & & & & \\
\hline Megalonaias nervosa & Washboard & & & & \\
\hline Obovaria jacksoniana & Southern hickorynut & 9.72 & 1.72 & 1.41 & 0.78 \\
\hline Obovaria unicolor & Alabama hickorynut & & 0.86 & & \\
\hline Pleurobema decisum & Southern clubshell & 1.39 & & 2.11 & 1.56 \\
\hline Pleurobema perovatum & Ovate clubshell & 6.94 & & & \\
\hline Potamilus purpuratus & Bleufer & & & & 0.78 \\
\hline Pyganodon grandis & Giant floater & & 0.86 & & \\
\hline Quadrula asperata & Alabama orb & 25 & 47.41 & 39.44 & 31.25 \\
\hline Quadrula rumphiana & Ridged mapleleaf & & & & 0.78 \\
\hline Strophitus subvexus & Southern creekmussel & 1.39 & & 1.41 & \\
\hline Toxolasma parva & Lilliput & & & 0.7 & 2.34 \\
\hline Tritogonia verrucosa & Pistolgrip & 16.67 & 6.03 & 23.94 & 18.75 \\
\hline Truncilla donaciformis & Fawnsfoot & 1.39 & & & \\
\hline Villosa lienosa & Little spectaclecase & & 2.59 & & 3.91 \\
\hline Villosa vibex & Southern rainbow & 1.39 & 0.86 & 0.7 & \\
\hline \multicolumn{2}{|l|}{ Total Individuals } & 72 & 123 & 142 & 128 \\
\hline \multicolumn{2}{|l|}{ Total species } & 11 & 14 & 14 & 15 \\
\hline \multicolumn{2}{|l|}{ Individuals collected / min } & ND & 0.085 & 0.153 & 0.149 \\
\hline
\end{tabular}




\begin{tabular}{|c|c|c|c|c|c|c|c|}
\hline \begin{tabular}{||l} 
Table 6 \\
Freshwater Musse \\
area,' was publish \\
Schultz (1981), ano \\
Although not listed \\
least since 1980 (S
\end{tabular} & $\begin{array}{l}\text { of Luxapalila Creek } \\
\text { d in Hartfield and Bo } \\
\text { historical informatio } \\
\text { C. fluminea has bee } \\
\text { hultz 1981). (E = Enc }\end{array}$ & $\begin{array}{l}1980 \text { to } \\
\text { ker }(19 \\
\text { as wel } \\
\text { collect } \\
\text { ngered }\end{array}$ & $\begin{array}{l}\text { Present. } \\
2 \text { ), incluc } \\
\text { as result } \\
\text { d regula } \\
\mathrm{T}=\text { Thre }\end{array}$ & $\begin{array}{l}\text { Column } \\
\text { des infol } \\
\text { ts of rec } \\
\text { rly from } \\
\text { atened) }\end{array}$ & $\begin{array}{l}4,1 \\
\text { rmati } \\
\text { ent c } \\
\text { Luxa }\end{array}$ & $\begin{array}{l}\text { sels } \\
\text { obtai } \\
\text { ctio } \\
\text { ila C }\end{array}$ & $\begin{array}{l}\text { n the } \\
\text { by }\end{array}$ \\
\hline & & Schultz & $\begin{array}{l}\begin{array}{l}\text { Hartfield \& } \\
\text { Bowker }\end{array} \\
\end{array}$ & $\begin{array}{l}\text { Mussels } \\
\text { From the }\end{array}$ & & ERDC S & \\
\hline Species & Common Name & 1980 & 1992 & Area & 1997 & 1998 & 1999 \\
\hline |Anodonta suborbiculata & Flat floater & & & & $x$ & & \\
\hline Elliptio arctata & Delicate spike & $x$ & & $x$ & & $x$ & $x$ \\
\hline Elliptio arca & Alabama spike & & & $x$ & & & \\
\hline |Elliptio crassidens & Elephant-ear & $x$ & & $x$ & & $x$ & $x$ \\
\hline |Fusconaia cerina & Gulf pigtoe & & $x$ & $x$ & $x$ & $x$ & $x$ \\
\hline ||Lampsilis s. claibornensis & Southern fatmucket & $x$ & $x$ & $x$ & $x$ & $x$ & $x$ \\
\hline Lampsilis ornata & Southern pocketbook & $x$ & $x$ & $x$ & $x$ & $x$ & $x$ \\
\hline Lampsilis perovalis & Orange-nacre mucket $(T)$ & & $x$ & $x$ & $x$ & & $x$ \\
\hline Lampsilis teres & Yellow sandshell & $x$ & & $x$ & $x$ & $x$ & $x$ \\
\hline Lasmigonia c. complanata & White heelsplitter & & & & $x$ & & \\
\hline Leptodea fragilis & Papershell & & & & & $x$ & \\
\hline Medionidus acutissimus & Alabama moccasinshell $(\mathrm{T})$ & & & $x$ & & & \\
\hline Megalonaias nervosa & Washboard & & & $x$ & & & \\
\hline Obovaria jacksoniana & Southern hickorynut & $x$ & $x$ & $x$ & $x$ & $x$ & $x$ \\
\hline Obovaria unicolor & Alabama hickorynut & & & & $x$ & & \\
\hline Pleurobema decisum & Southern clubshell $(E)$ & $x$ & $x$ & $x$ & & $x$ & $x$ \\
\hline Pleurobema perovatum & Ovate clubshell (E) & $x$ & & $x$ & & & \\
\hline |Potamilus purpuratus & Bleufer & & & $x$ & & & $x$ \\
\hline ||Pyganodon grandis & Giant floater & & & & $x$ & & \\
\hline Quadrula asperata & Alabama orb & $x$ & $x$ & $x$ & $x$ & $x$ & $x$ \\
\hline Quadrula rumphiana & Ridged mapleleaf & & & & & & $x$ \\
\hline Strophitus subvexus & Southern creekmussel & $x$ & $x$ & $x$ & & $x$ & \\
\hline |Toxolasma parva & Lilliput & & & $x$ & & $x$ & $x$ \\
\hline Tritogonia verrucosa & Pistolgrip & $x$ & $x$ & $x$ & $x$ & $x$ & $x$ \\
\hline Truncilla donaciformis & Fawnsfoot & & $x$ & $x$ & & & \\
\hline Villosa lienosa & Little spectaclecase & $x$ & & $x$ & $x$ & & $x$ \\
\hline Villosa vibex & Southern rainbow & $x$ & $x$ & $x$ & $x$ & $x$ & \\
\hline Total species & 27 & 13 & 11 & 21 & 14 & 14 & 15 \\
\hline
\end{tabular}




\section{Appendix A Tables}

\begin{tabular}{|c|c|c|c|c|c|c|}
\hline \multicolumn{7}{|c|}{$\begin{array}{l}\text { Table A1 } \\
\text { Summary of } 3 \text { Years }(1997,1998, \text { and 1999) of Sampling for Freshwater Bivalves at Sites } \\
1 \text { and } 2 \text { on Luxapalila Creek, Mississippi }\end{array}$} \\
\hline \multirow[b]{2}{*}{ Species } & \multicolumn{3}{|c|}{ Site 1} & \multicolumn{3}{|c|}{ Site 2} \\
\hline & 1997 & 1998 & 1999 & 1997 & 1998 & 1999 \\
\hline Quadrula asperata & $\overline{11}$ & & & 29 & 39 & 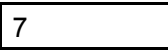 \\
\hline Lampsilis ornata & & 1 & 1 & 6 & 7 & 1 \\
\hline Lampsilis s. claibornensis & & & & 13 & 6 & 3 \\
\hline Tritogonia verrucosa & & & 3 & 3 & 27 & \\
\hline Corbicula fluminea & 1 & & & 1 & & \\
\hline Fusconaia cerina & & & & & 1 & 1 \\
\hline Villosa lienosa & & & & 2 & & \\
\hline Obovaria jacksoniana & & & & 1 & 1 & 1 \\
\hline Obovaria unicolor & & & & 1 & & \\
\hline \multicolumn{7}{|l|}{ Lampsilis perovalis } \\
\hline Lampsilis complanata & & & & 1 & & \\
\hline Villosa vibex & & & & & 1 & \\
\hline \multicolumn{7}{|l|}{ Pyganodon suborbiculata } \\
\hline \multicolumn{7}{|l|}{ Pyganodon grandis } \\
\hline Lampsilis teres & & & & & 1 & \\
\hline \multicolumn{7}{|l|}{ Elliptio arctata } \\
\hline \multicolumn{7}{|l|}{ Elliptio crassidens } \\
\hline Leptodea fragilis & & & & & 1 & \\
\hline Pleurobema decisum & & & & & 2 & \\
\hline Strophitus subvexus & & & & & 2 & \\
\hline Toxolasma parva & & & & & & 1 \\
\hline Potamilus purpuratus & & & & & & 1 \\
\hline \multicolumn{7}{|l|}{ Quadrula rumphiana } \\
\hline Total individuals & 2 & 1 & 4 & 57 & 88 & 15 \\
\hline Total species & 2 & 1 & 2 & 9 & 11 & 7 \\
\hline Total time $(\mathrm{min})$ & 178 & 106 & 90 & 205 & 101 & 90 \\
\hline Total time (hr) & 3.0 & 1.8 & 1.5 & 3.4 & \begin{tabular}{|l|l} 
\\
\end{tabular} & 1.5 \\
\hline Individuals/min & 0.011 & 0.009 & 0.044 & 0.278 & 0.871 & 0.167 \\
\hline
\end{tabular}




\begin{tabular}{|c|c|c|c|c|c|c|}
\hline \multicolumn{7}{|c|}{$\begin{array}{l}\text { Table A2 } \\
\text { Summary of } 3 \text { Years }(1997,1998, \text { and 1999) of Sampling for Freshwater Bivalves at Sites } \\
3 \text { and } 4 \text { on Luxapalila Creek, Mississippi }\end{array}$} \\
\hline \multirow[b]{2}{*}{ Species } & \multicolumn{3}{|c|}{ Site 3} & \multicolumn{3}{|c|}{ Site 4} \\
\hline & 1997 & 1998 & 1999 & 1997 & 1998 & 1999 \\
\hline Quadrula asperata & & & & & 6 & 3 \\
\hline Lampsilis ornata & & & & & 6 & 1 \\
\hline Lampsilis s. claibornensis & & & & & 2 & 1 \\
\hline Tritogonia verrucosa & & & & & 4 & 2 \\
\hline Corbicula fluminea & & 1 & & & 1 & \\
\hline Fusconaia cerina & & & & & 2 & 1 \\
\hline \multicolumn{7}{|l|}{ Villosa lienosa } \\
\hline \multicolumn{7}{|l|}{ Obovaria jacksoniana } \\
\hline \multicolumn{7}{|l|}{ Obovaria unicolor } \\
\hline Lampsilis perovalis & & & & 1 & & 1 \\
\hline \multicolumn{7}{|l|}{ Lampsilis complanata } \\
\hline Villosa vibex & & & & 1 & & \\
\hline \multicolumn{7}{|l|}{ Pyganodon suborbiculata } \\
\hline \multicolumn{7}{|l|}{ Pyganodon grandis } \\
\hline \multicolumn{7}{|l|}{ Lampsilis teres } \\
\hline Elliptio arctata & & & & & 1 & \\
\hline Elliptio crassidens & & & & & 1 & \\
\hline \multicolumn{7}{|l|}{ Leptodea fragilis } \\
\hline \multicolumn{7}{|l|}{ Pleurobema decisum } \\
\hline \multicolumn{7}{|l|}{ Strophitus subvexus } \\
\hline \multicolumn{7}{|l|}{ Toxolasma parva } \\
\hline \multicolumn{7}{|l|}{ Potamilus purpuratus } \\
\hline \multicolumn{7}{|l|}{ Quadrula rumphiana } \\
\hline Total individuals & 0 & 1 & 0 & 2 & 23 & 9 \\
\hline Total species & 0 & 1 & 0 & 2 & 8 & 6 \\
\hline Total time (min) & 30 & 112 & 0 & 105 & 60 & 90 \\
\hline Total time (hr) & 0.5 & 1.9 & 0.0 & 1.8 & 1.0 & 1.5 \\
\hline Individuals/min & 0.000 & 0.009 & 0.000 & 0.019 & 0.383 & 0.100 \\
\hline
\end{tabular}


Table A3

Summary of 3 Years $(1997,1998$, and 1999) of Sampling for Freshwater Bivalves at Sites 5 and 6 on Luxapalila Creek, Mississippi

\begin{tabular}{|c|c|c|c|c|c|c|}
\hline \multirow[b]{2}{*}{ Species } & \multicolumn{3}{|c|}{ Site 5} & \multicolumn{3}{|c|}{ Site 6} \\
\hline & 1997 & 1998 & 1999 & 1997 & 1998 & 1999 \\
\hline Quadrula asperata & & 2 & & 6 & 7 & 22 \\
\hline Lampsilis ornata & & 1 & 2 & & 2 & 6 \\
\hline Lampsilis s. claibornensis & & & & 7 & 6 & 12 \\
\hline Tritogonia verrucosa & & & 5 & 3 & 2 & 6 \\
\hline \multicolumn{7}{|l|}{ Corbicula fluminea } \\
\hline Fusconaia cerina & & & 1 & & & \\
\hline Villosa lienosa & 1 & & & & & 4 \\
\hline Obovaria jacksoniana & & & & & 1 & \\
\hline \multicolumn{7}{|l|}{ Obovaria unicolor } \\
\hline Lampsilis perovalis & & & & & & 2 \\
\hline \multicolumn{7}{|l|}{ Lampsilis complanata } \\
\hline \multicolumn{7}{|l|}{ Villosa vibex } \\
\hline \multicolumn{7}{|l|}{ Pyganodon suborbiculata } \\
\hline \multicolumn{7}{|l|}{ Pyganodon grandis } \\
\hline Lampsilis teres & & & & & & 1 \\
\hline \multicolumn{7}{|l|}{ Elliptio arctata } \\
\hline Elliptio crassidens & & & 1 & & & \\
\hline \multicolumn{7}{|l|}{ Leptodea fragilis } \\
\hline \multicolumn{7}{|l|}{ Pleurobema decisum } \\
\hline \multicolumn{7}{|l|}{ Strophitus subvexus } \\
\hline Toxolasma parva & & & & & & 2 \\
\hline \multicolumn{7}{|l|}{ Potamilus purpuratus } \\
\hline Quadrula rumphiana & & & 1 & & & \\
\hline Total individuals & 1 & 3 & 10 & 16 & 18 & 55 \\
\hline Total species & 1 & 2 & 5 & 3 & 5 & 8 \\
\hline Total time (min) & 105 & 80 & 90 & 175 & 96 & 90 \\
\hline Total time (hr) & 1.8 & 1.3 & 1.5 & 2.9 & 1.6 & 1.5 \\
\hline Individuals/min & 0.010 & 0.038 & 0.111 & 0.091 & 0.188 & 0.611 \\
\hline
\end{tabular}




\begin{tabular}{|c|c|c|c|c|c|c|}
\hline \multicolumn{7}{|c|}{$\begin{array}{l}\text { Table A4 } \\
\text { Summary of } 3 \text { Years }(1997,1998, \text { and 1999) of Sampling for Freshwater Bivalves at Sites } \\
7 \text { and } 8 \text { on Luxapalila Creek, Mississippi }\end{array}$} \\
\hline \multirow[b]{2}{*}{ Species } & \multicolumn{3}{|c|}{ Site 7} & \multicolumn{3}{|c|}{ Site 8} \\
\hline & 97 & 98 & 99 & 97 & 98 & 99 \\
\hline Quadrula asperat & & & & 2 & & 1 \\
\hline Lampsilis ornata & & & & 3 & & 4 \\
\hline \multicolumn{7}{|c|}{ Lampsilis s. claibornensis } \\
\hline \multicolumn{7}{|c|}{ Tritogonia verrucosa } \\
\hline \multicolumn{7}{|l|}{ Corbicula fluminea } \\
\hline \multicolumn{7}{|l|}{ Fusconaia cerina } \\
\hline \multicolumn{7}{|l|}{ Villosa lienosa } \\
\hline \multicolumn{7}{|c|}{ Obovaria jacksoniana } \\
\hline \multicolumn{7}{|l|}{ Obovaria unicolor } \\
\hline \multicolumn{7}{|c|}{ Lampsilis perovalis } \\
\hline \multicolumn{7}{|c|}{ Lampsilis complanata } \\
\hline \multicolumn{7}{|l|}{ Villosa vibex } \\
\hline \multicolumn{7}{|c|}{ Pyganodon suborbiculata } \\
\hline \multicolumn{7}{|c|}{ Pyganodon grandis } \\
\hline \multicolumn{7}{|l|}{ Lampsilis teres } \\
\hline Elliptio arctata & & 1 & & & & \\
\hline \multicolumn{7}{|l|}{ Elliptio crassidens } \\
\hline \multicolumn{7}{|l|}{ Leptodea fragilis } \\
\hline \multicolumn{7}{|c|}{ Pleurobema decisum } \\
\hline \multicolumn{7}{|c|}{ Strophitus subvexus } \\
\hline Toxolasma parva & & 1 & & & & \\
\hline \multicolumn{7}{|c|}{ Potamilus purpuratus } \\
\hline \multicolumn{7}{|c|}{ Quadrula rumphiana } \\
\hline Total individuals & 0 & 2 & 0 & 5 & 0 & 5 \\
\hline Total species & 0 & 2 & 0 & 2 & 0 & 2 \\
\hline Total time (min) & 167 & 90 & 90 & 120 & 90 & 90 \\
\hline Total time (hr) & 2.8 & 1.5 & 1.5 & 2.0 & 1.5 & 1.5 \\
\hline Individuals/min & 0.000 & 0.022 & 0.000 & 0.042 & 0.000 & 0.056 \\
\hline
\end{tabular}




\begin{tabular}{|c|c|c|c|c|c|c|}
\hline \multicolumn{7}{|c|}{$\begin{array}{l}\text { Table A5 } \\
\text { Summary of } 3 \text { Years }(1997,1998, \text { and 1999) of Sampling for Freshwater Bivalves } \\
\text { at Sites } 9 \text { and } 10 \text { on Luxapalila Creek, Mississippi }\end{array}$} \\
\hline \multirow[b]{2}{*}{ Species } & \multicolumn{3}{|c|}{ Site 9} & \multicolumn{3}{|c|}{ Site 10} \\
\hline & 1997 & 1998 & 1999 & 1997 & 1998 & 1999 \\
\hline Quadrula asperata & & & & 17 & 2 & 3 \\
\hline Lampsilis ornata & & & & 4 & 1 & 2 \\
\hline Lampsilis s. claibornensis & 1 & & 2 & 3 & 2 & \\
\hline Tritogonia verrucosa & 1 & & 3 & & 1 & 2 \\
\hline Corbicula fluminea & & 1 & & 5 & & \\
\hline Fusconaia cerina & 1 & & 1 & 4 & & \\
\hline Villosa lienosa & & & & & & 1 \\
\hline Obovaria jacksoniana & & & & 1 & & \\
\hline \multicolumn{7}{|l|}{ Obovaria unicolor } \\
\hline \multicolumn{7}{|l|}{ Lampsilis perovalis } \\
\hline \multicolumn{7}{|l|}{ Lampsilis complanata } \\
\hline \multicolumn{7}{|l|}{ Villosa vibex } \\
\hline Pyganodon suborbiculata & & & & 1 & & \\
\hline Pyganodon grandis & & & & 1 & & \\
\hline Lampsilis teres & & & & 1 & & \\
\hline Elliptio arctata & & & & & 1 & \\
\hline \multicolumn{7}{|l|}{ Elliptio crassidens } \\
\hline \multicolumn{7}{|l|}{ Leptodea fragilis } \\
\hline Pleurobema decisum & & & & & 1 & \\
\hline \multicolumn{7}{|l|}{ Strophitus subvexus } \\
\hline \multicolumn{7}{|l|}{ Toxolasma parva } \\
\hline \multicolumn{7}{|l|}{ Potamilus purpuratus } \\
\hline \multicolumn{7}{|l|}{ Quadrula rumphiana } \\
\hline Total individuals & 3 & 1 & 6 & 37 & 8 & 8 \\
\hline Total species & 3 & 1 & 3 & 9 & 6 & 4 \\
\hline Total time (min) & 90 & 72 & 90 & 190 & 80 & 90 \\
\hline Total time (hr) & 1.5 & 1.2 & 1.5 & 3.2 & 1.3 & 1.5 \\
\hline Individuals/min & 0.033 & 0.014 & 0.067 & 0.195 & 0.100 & 0.089 \\
\hline
\end{tabular}




\begin{tabular}{|c|c|c|c|c|c|c|}
\hline \multicolumn{7}{|c|}{$\begin{array}{l}\text { Table A6 } \\
\text { Summary of } 1 \text { Year (1999) of Sampling for Freshwater Bivalves at Sites 10a and 10b on } \\
\text { Luxapalila Creek, Mississippi (NS = Not Sampled) }\end{array}$} \\
\hline \multirow[b]{3}{*}{ Species } & \multicolumn{3}{|c|}{ Site 10a } & \multicolumn{3}{|c|}{ Site 10b } \\
\hline & 1997 & 1998 & 1999 & 1997 & 1998 & 1999 \\
\hline & NS & NS & & NS & NS & \\
\hline Quadrula asperata & & & 5 & & & \\
\hline \multicolumn{7}{|l|}{ Lampsilis ornata } \\
\hline Lampsilis s. claibornensis & & & 3 & & & \\
\hline Tritogonia verrucosa & & & 3 & & & \\
\hline \multicolumn{7}{|l|}{ Corbicula fluminea } \\
\hline Fusconaia cerina & & & 1 & & & \\
\hline \multicolumn{7}{|l|}{ Villosa lienosa } \\
\hline \multicolumn{7}{|l|}{ Obovaria jacksoniana } \\
\hline \multicolumn{7}{|l|}{ Obovaria unicolor } \\
\hline \multicolumn{7}{|l|}{ Lampsilis perovalis } \\
\hline \multicolumn{7}{|l|}{ Lampsilis complanata } \\
\hline \multicolumn{7}{|l|}{ Villosa vibex } \\
\hline \multicolumn{7}{|l|}{ Pyganodon suborbiculata } \\
\hline \multicolumn{7}{|l|}{ Pyganodon grandis } \\
\hline \multicolumn{7}{|l|}{ Lampsilis teres } \\
\hline Elliptio arctata & & & 1 & & & \\
\hline Elliptio crassidens & & & 1 & & & \\
\hline \multicolumn{7}{|l|}{ Leptodea fragilis } \\
\hline Pleurobema decisum & & & 2 & & & \\
\hline \multicolumn{7}{|l|}{ Strophitus subvexus } \\
\hline \multicolumn{7}{|l|}{ Toxolasma parva } \\
\hline \multicolumn{7}{|l|}{ Potamilus purpuratus } \\
\hline \multicolumn{7}{|l|}{ Quadrula rumphiana } \\
\hline Total individuals & 0 & 0 & 16 & 0 & 0 & 0 \\
\hline Total species & 0 & 0 & 7 & 0 & 0 & 0 \\
\hline Total time (min) & 0 & 0 & 45 & 0 & 0 & 45 \\
\hline Total time (hr) & 0.0 & 0.0 & 0.8 & 0.0 & 0.0 & 0.8 \\
\hline Individuals/min & 0.000 & 0.000 & 0.356 & 0.000 & 0.000 & 0.000 \\
\hline
\end{tabular}




\begin{tabular}{|c|c|c|c|}
\hline \multicolumn{4}{|c|}{$\begin{array}{l}\text { Table A7 } \\
\text { Summary of } 2 \text { Years (1998 and 1999) of Sampling for Freshwater } \\
\text { Bivalves at Site } 11 \text { on Luxapalila Creek, Mississippi (NS = Not Sampled) }\end{array}$} \\
\hline \multirow[b]{3}{*}{ Species } & \multicolumn{3}{|c|}{ Site 11} \\
\hline & 97 & 98 & 99 \\
\hline & NS & & \\
\hline \multicolumn{4}{|c|}{ Quadrula asperata } \\
\hline \multicolumn{4}{|l|}{ Lampsilis ornata } \\
\hline \multicolumn{4}{|c|}{ Lampsilis s. claibornensis } \\
\hline \multicolumn{4}{|c|}{ Tritogonia verrucosa } \\
\hline \multicolumn{4}{|c|}{ Corbicula fluminea } \\
\hline \multicolumn{4}{|l|}{ Fusconaia cerina } \\
\hline \multicolumn{4}{|l|}{ Villosa lienosa } \\
\hline \multicolumn{4}{|c|}{ Obovaria jacksoniana } \\
\hline \multicolumn{4}{|c|}{ Obovaria unicolor } \\
\hline \multicolumn{4}{|c|}{ Lampsilis perovalis } \\
\hline \multicolumn{4}{|c|}{ Lampsilis complanata } \\
\hline \multicolumn{4}{|l|}{ Villosa vibex } \\
\hline \multicolumn{4}{|c|}{ Pyganodon suborbiculata } \\
\hline \multicolumn{4}{|c|}{ Pyganodon grandis } \\
\hline \multicolumn{4}{|l|}{ Lampsilis teres } \\
\hline \multicolumn{4}{|l|}{ Elliptio arctata } \\
\hline \multicolumn{4}{|c|}{ Elliptio crassidens } \\
\hline \multicolumn{4}{|l|}{ Leptodea fragilis } \\
\hline \multicolumn{4}{|c|}{ Pleurobema decisum } \\
\hline \multicolumn{4}{|c|}{ Strophitus subvexus } \\
\hline \multicolumn{4}{|l|}{ Toxolasma parva } \\
\hline \multicolumn{4}{|c|}{ Potamilus purpuratus } \\
\hline \multicolumn{4}{|c|}{ Quadrula rumphiana } \\
\hline Total individuals & 0 & 0 & 0 \\
\hline Total species & 0 & 1 & 0 \\
\hline Total time (min) & 0 & 80 & 30 \\
\hline Total time (hr) & 0.0 & 1.3 & 0.5 \\
\hline Individuals/min & 0.000 & 0.000 & 0.000 \\
\hline
\end{tabular}




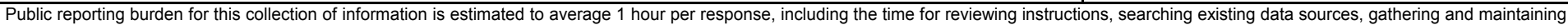

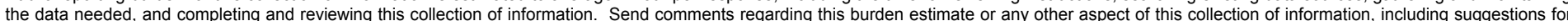

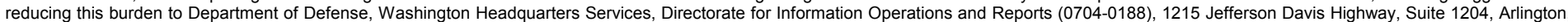

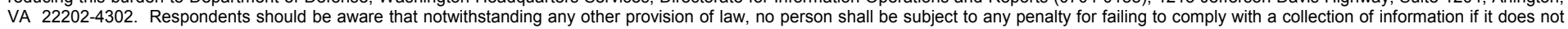
display a currently valid OMB control number. PLEASE DO NOT RETURN YOUR FORM TO THE ABOVE ADDRESS.

\begin{tabular}{l|c}
$\begin{array}{l}\text { 1. REPORT DATE }(D D-M M-Y Y Y Y) \\
\text { September } 2001\end{array}$ & $\begin{array}{c}\text { 2. REPORT TYPE } \\
\text { Final report }\end{array}$ \\
\hline
\end{tabular}

4. TITLE AND SUBTITLE

An Analysis of Freshwater Mussels (Unionidae) Along Luxapalila Creek,

Mississippi, 1999 Studies

3. DATES COVERED (From - To)

5a. CONTRACT NUMBER

5b. GRANT NUMBER

5c. PROGRAM ELEMENT NUMBER

6. AUTHOR(S)

Andrew C. Miller

5d. PROJECT NUMBER 5e. TASK NUMBER

5f. WORK UNIT NUMBER

8. PERFORMING ORGANIZATION REPORT NUMBER

ERDC/EL TR-01-26

U.S. Army Engineer Research and Development Center

Environmental Laboratory

3909 Halls Ferry Road

Vicksburg, MS 39180-6199

9. SPONSORING / MONITORING AGENCY NAME(S) AND ADDRESS(ES)

10. SPONSOR/MONITOR'S ACRONYM(S)

U.S. Army Engineer District, Mobile

Mobile, AL 36628-0001

11. SPONSOR/MONITOR'S REPORT NUMBER(S)

\section{DISTRIBUTION / AVAILABILITY STATEMENT}

Approved for public release; distribution is unlimited

\section{SUPPLEMENTARY NOTES}

\section{ABSTRACT}

In October 1999, 14 sites along Luxapalila Creek between Steens, Mississippi, and Waterworks Road Bridge (River Mile 6.2), were searched for freshwater mussels (Family: Unionidae). All collecting was done by hand and without divers. The purpose was to obtain information that could be used to assess the effectiveness of reasonable and prudent measures and their terms and conditions to reduce impacts to mussels caused by downstream channelization that took place in 1994 to 1996. In addition, results would be used to determine the likelihood of future losses (or incidental take) of federally listed mussel species in the project area. Fifteen species of freshwater mussels, in addition to Corbicula fluminea (Asian clam), were collected. Live specimens of the endemic, federally listed threatened Pleurobema decisum (southern clubshell) was collected at one site. The most abundant living species were Quadrula asperata (Alabama orb) and Lampsilis straminea claibornensis (southern fatmucket) which comprised 31.2 and 19.5 percent of the fauna. The third and fourth most abundant species, Tritogonia verrucosa (pistolgrip) and Lampsilis ornata (southern pocketbook), comprised 18.7 and 10.9 percent of the collection. The remaining 11 species each comprised less than 4 percent of the fauna. Mussel abundance has changed little in this stream, based upon results of a survey conducted in 1992 and studies conducted in 1997 and 1998.

\section{SUBJECT TERMS}

Luxapalila Creek, Mississippi Unionidae

Mussels

16. SECURITY CLASSIFICATION OF:

\section{a. REPORT}

UNCLASSIFIED

b. ABSTRACT
UNCLASSIFIED

17. LIMITATION OF ABSTRACT

\begin{tabular}{|c|c|}
\hline $\begin{array}{c}\text { 18. NUMBER } \\
\text { OF PAGES }\end{array}$ & \\
\cline { 2 - 2 } & \\
&
\end{tabular}

19a. NAME OF RESPONSIBLE PERSON

19b. TELEPHONE NUMBER (include area code) 